\title{
Analisis Pembiayaan Program Kesehatan Ibu dan Anak (KIA) terhadap Indikator Capaian sesuai Standar Pelayanan Minimal (SPM) bidang Kesehatan di Dinas Kesehatan Kota Jambi Tahun 2016
}

\section{Analysis Financing Maternal and Child Health (MCH) against the corresponding Indicators of Minimum Service Standards (MSS) in the health sector at Jambi City Health Department 2016}

\author{
Hubaybah $^{1,}$ Dwi Noerjoedianto ${ }^{1}$ \\ ${ }^{1}$ Program Studi Ilmu Kesehatan Masyarakat Universitas Jambi
}

\begin{abstract}
Abstrak
Dalam rangka penyelenggaraan pembangunan kesehatan, perlu adanya pembiayaan kesehatan, yang bertujuan untuk penyediaan pembiayaan kesehatan yang berkesinambungan dengan jumlah yang mencukupi, teralokasi secara adil dan termanfaatkan secara berhasil guna dan berdaya guna. Penelitian ini menggunakan pendekatan deskriptif, kualitatif. Tujuan penelitian ini adalah mengetahui perencanaan dan realisasi anggaran program KIA, menganalisis pembiayaan program KIA terhadap indikator capaian sesuai SPM di Dinas Kesehatan Kota Jambi tahun 2016. Penelitian ini dilaksanakan di Dinas Kesehatan Kota Jambi dengan waktu penelitian dari bulan Mei September 2017. Hasil penelitian ini menunjukkan seluruh aktifitas Standar Pelayanan Minimal (SPM) tahun 2016 mengalami presentasi peningkatan yang signifikan antara target dan realisasi masing-masing cakupan pelayanan kecuali hanya dua cakupan pelayanan yang belum memenuhi target. Hal ini menandakan bahwa target yang ingin dicapai oleh dinas kesehatan Kota Jambi dianggap melibihi target yang di rencanakan. Namun demikian data diatas juga menunjukkan terdapat beberapa cakupan pelayanan yang belum memenuhi target yang ingin dicapai, seperti pada cakupan Neonatus dengan komplikasi yang ditangani, dimana target yang ingin dicapai $80 \%$ sedangkan realisasinya hanya 55\%. Kemudian cakupan peserta KB aktif dimana target yang ingin dicapai $70 \%$ sedangkan realisasinya hanya $62 \%$.
\end{abstract}

Kata Kunci: Analisis, Pembiayaan, Kesehatan Ibu dan Anak

\begin{abstract}
In the framework of the implementation of health development, the need for health financing, aimed at providing sustainable health financing with a sufficient amount, allocated in a fair and successfully utilized effectively and efficiently. This research use desciptive qualitative approach. The purpose of this study is know the planning and realization of the program budget $\mathrm{MCH}, \mathrm{MCH}$ programs to analyze the financing of indicators according MSS in Jambi City Health Department in 2016. The research was conducted in Jambi City Health Department with research time from May September 2017. The results showed all the activities of the Minimum Service Standards (MSS) in 2016 experienced a significant improvement presentation between the target and the realization of each service coverage but only two service coverage has not met the target. This indicates that the target to be achieved by the health department considered melibihi Jambi city from planned targets. However, the above data also shows there are some services that do not meet the coverage targets to be achieved, such as the scope of the neonate with complications were handled, where the targets to achieve $80 \%$ while the realization was only $55 \%$. Then the active coverage of family planning where the targets to achieve $70 \%$ while the realization was only $62 \%$.
\end{abstract}

Keywords: Analysis, Financing, Maternal and Child Health

Korespondensi: Dwi Noerjoedianto

Email: masyudi_psik99@yahoo.com 


\section{PENDAHULUAN}

Dalam rangka penyelenggaraan pembangunan kesehatan, perlu adanya pembiayaan kesehatan, yang bertujuan untuk penyediaan pembiayaan kesehatan yang berkesinambungan dengan jumlah yang mencukupi, teralokasi secara adil dan termanfaatkan secara berhasil guna dan berdaya guna. Untuk itu perlu diselenggarakan upaya kesehatan yang terpadu dan menyeluruh dalam bentuk upaya kesehatan perorangan dan upaya kesehatan masyarakat, yang diselenggarakan dalam bentuk kegiatan dengan pendekatan promotif, preventif, kuratif dan rehabilitatif yang dilaksanakan secara terpadu, menyeluruh, dan berkesinambungan.

Penyelenggaran urusan pemerintah yang bersifat wajib, berpedoman pada standar pelayanan minimal dilaksanakan secara bertahap dan ditetapkan pemerintah. Guna memberikan panduan dalam melaksanakan urusan wajib pada bidang kesehatan telah ditetapkan Keputusan Menteri Kesehatan RI nomor: 43 Tahun 2016 tentang Standar Pelayanan Minimal Bidang Kesehatan ${ }^{1}$.

Standar Pelayanan Minimal (SPM) adalah ketentuan tentang jenis dan mutu pelayanan dasar yang merupakan urusan wajib daerah yang berhak diperoleh setiap warga secara minimal. Adapun pelayanan dasar adalah jenis pelayanan publik yang mendasar dan mutlak untuk memenuhi kebutuhan masyarakat dalam kehidupan sosial, ekonomi, dan pemerintah $^{2}$.

Untuk pencapaian target SPM, Dinas Kesehatan mempunyai upaya kesehatan wajib yang dikenal dengan basic six yang meliputi promosi kesehatan, KIA dan KB, Imunisasi, pemberantasan penyakit menular, gizi dan balai pengobatan di samping dapat melaksanakan upaya kesehatan pilihan seperti usaha kesehatan sekolah $^{3}$.
Urusan pemerintah yang diserahkan kepada daerah disertai dengan sumber pendanaan, pengalihan sarana prasarana, serta kepegawaian sesuai dengan urusan yang di desentralisasikan ${ }^{4}$. Pemerintah daerah guna pelaksanaan urusan wajib sesuai dengan standar pelayanan minimal perlu membuat perencanaan dan menghitung berapa besar jumlah anggaran untuk pelaksanaan urusan tersebut.

Proses penyusunan perencanaan mempunyai langkah-langkah yang saling berkaitan. Adapun perhitungan anggaran dalam teori dikenal line item budgeting" dan performance budgeting" line item budgeting pada saat ini sudah banyak ditinggalkan karena mempunyai kelemahan yaitu tidak adanya kejelasan hubungan antara belanja barang dan jasa yang digunakan dengan output atau kinerja program $^{5}$.

Performance budgeting (anggaran berbasis kinerja) pada akhir-akhir ini menjadi pilihan dalam penyusunan perencanaan penganggaran sesuai dengan Keputusan Menteri Dalam Negeri Nomor 29 tahun 2002 yang telah diubah menjadi Peraturan Menteri Dalam Negeri Nomor 13 tahun 2006. Pada performance budgeting didasarkan pada adanya kesinambungan antara output atau kinerja kegiatan dengan input atau anggaran yang dibutuhkan ${ }^{5}$.

Salah satu tantangan yang dihadapi oleh sebagian besar kabupaten/kota di Indonesia adalah tingginya Angka Kematian Ibu (AKI), begitu juga di Provinsi Jambi dimana jumlah kematian ibu per-Kab/Kota pada tahun 2014 terbanyak di Kota Jambi (9 kasus) ${ }^{6}$.

Dalam menghadapi tantangan ini, pemerintah kota Jambi telah berkomitmen dalam meningkatkan kualitas kesehatan. Namun yang masih dipertanyakan adalah sejauh mana komitmen ini tercermin dalam program anggaran pembiayaan kesehatan guna mencapai 
tujuan-tujuan kesehatan tersebut. Hasil penelitian sebelumnya menunjukkan bahwa rendahnya pembiayaan kesehatan suatu daerah dapat berdampak terhadap rendahnya pencapaian peningkatan upaya kesehatan di daerah tersebut.

Berdasar latar belakang tersebut penulis termotivasi untuk menelusuri sejauh mana penggunaan anggaran pembiayaan kesehatan terhadap capaian program KIA sesuai SPM di Dinas Kesehatan Kota Jambi selama tahun 2016. Melalui kajian ini juga diharapkan dapat secara komprehensif menilai tingkat responsive anggaran Dinas Kesehatan Kota Jambi dalam menjawab tantangan-tantangan untuk meningkatkan status kesehatan masyarakatnya. Disamping itu kajian ini juga akan diilengkapi dengan studi kualitatif melalui wawancara mendalam dengan para pembuat kebijakan publik (stakeholder terkait) dalam rangka memahami sejauh mana anggaran daerah tanggap terhadap permasalahan kesehatan yang dihadapi.

\section{METODE}

Penelitian ini menggunakan pendekatan deskriptif kualitatif yaitu dengan prosedur penelitiannya yang akan menghasilkan data-data deskriptif, kemudian dilakukan analisis dengan cara mendeskripsikan data sekunder dan primer yang dilakukan di lapangan, menganalisa, dan menyimpulkan untuk menjawab tujuan penelitian. Pembiayaan program disusun berdasarkan data primer dan sekunder yang bersumber dari Dinas Kesehatan Kota Jambi. Kemudian dilakukan identifikasi masalah yang meliputi perencanaan dan realisasi anggaran pembiayaan program KIA di Dinas Kesehatan Kota Jambi tahun 2016.. Penelitian ini dilaksanakan di Dinas Kesehatan Kota Jambi dengan waktu penelitian dari bulan Mei September 2017.
HASIL DAN PEMBAHASAN Analisis Tujuan Perencanaan Anggaran Program KIA Dinas Kesehatan Kota Jambi

Gambaran tentang tujuan perencanaan anggaran program KIA pada penelitian ini meliputi hubungan/pengaruh antara masalah kesehatan, kinerja program KIA dan pengaruh faktor lingkungan serta perilaku terhadap perencanaan penganggaran pada Dinas Kesehatan Kota Jambi.

Hasil wawancara mendalam dengan beberapa informan dari Dinas Kesehatan Kota Jambi didapati bahwa: (1) Masalah kesehatan berpengaruh terhadap perencanaan yang telah disusun oleh Dinas Kesehatan Kota Jambi, di antaranya untuk dijadikan dasar dalam penentuan prioritas kegiatan. (2) Masalah kesehatan tidak berpengaruh terhadap penganggaran karena dalam penghitungan anggarannya sifatnya rutinitas dan anggaran sudah ditentukan sehingga ada yang melakukan copy paste pada anggaran/kegiatan tahun lalu. Namun ada juga informan menyatakan berpengaruh karena masalah kesehatan dijadikan dasar dalam penentuan prioritas kegiatan yang akan dibiayai. (3) Hubungan analisis kinerja program dengan perencanaan anggaran menunjukkan sebagian besar informan menyatakan kinerja program dibutuhkan dalam perencanaan penganggaran, karena akan dijadikan dasar dalam penentuan prioritas kegiatan. Disamping itu ada hubungan karena dilakukan copy paste perencanaan tahun sebelumnya. (4) Hubungan analisa faktor lingkungan dan perilaku dengan perencanaan penganggaran menunjukkan seluruh informan menyatakan dibutuhkan dan berpengaruh karena lingkungan dan perilaku berpengaruh besar terhadap keberhasilan program seperti keyakinan dan budaya masyarakat tentang pola pencarian pengobatan dan pertolongan persalinan. 
Berdasarkan hasil wawancara mendalam pada analisis situasi menunjukkan bahwa perencanaan anggaran yang disusun oleh Dinas Kesehatan Kota Jambi berdasarkan pada kinerja yang meliputi kinerja yang dicapai pada tahun lalu dan rencana pencapaian target tahun yang akan datang.

Setelah anggaran disusun dan diajukan untuk mendapatkan penetapan tidak seluruh perencanaan yang diusulkan mendapatkan anggaran. Dalam menyikapi anggaran yang tidak terpunuhi tersebut, maka dinas Kesehatan Kota Jambi melakukan beberapa langkah diantaranya pertama membuat skala prioritas dan kedua kegiatan tetap dilaksanakan dengan mencari sumber dana yang lain atau mengatur dana yang ada.

Hal ini memperkuat anggapan sebelumnya bahwa Dinas Kesehatan Kota Jambi mengkombinasikan pendekatan penyusunan anggaran budget based targeting dan target based budgeting artinya besarnya anggaran telah ditetapkan terlebih dahulu, baru setelah itu target dan jenis kegiatan disesuaikan dengan besarnya anggaran yang tersedia. Namun di sisi lain target yang harus dicapai juga telah ditetapkan terlebih dahulu pada Surat Keputusan Walikota, sehingga Dinas Kesehatan Kota Jambi tetap dapat melaksanakan seluruh kegiatan dengan dana yang ada dengan harapan target yang ingin di capai terealisasi.

Proses improvisasi yang dilakukan Dinas Kesehatan Kota Jambi dalam memenuhi transparansi dan akuntabilitas kemudian dibicarakan dan dilaporkan melalui forumforum yang ada seperti lokakarya bulanan atau mengadakan furum khusus untuk membahas dan mengevaluasi kegiatan dan pencapaian target berjalan.

\section{Analisis Realisasi Anggaran Program KIA.}

Variabel penelitian yang diteliti pada anggaran program KIA meliputi proses penghitungan anggaran, keterkaitan anggaran dengan SPM, realisasi anggaran, kecukupan anggaran, sumber anggaran, capaian target dan dasar pengalokasian anggaran. Berdasar hasil yang didapati dari informan, maka dapat disimpulkan beberapa hal sebagai berikut: (1) Dinas Kesehatan Kota Jambi melakukan proses penghitungan anggaran program KIA dengan cara mengikuti format yang ada mengisinya secara rinci, anggaran mengikuti kegiatan yang telah disusun. (2) Perhitungan anggaran di Dinas Kesehatan pada prinsipnya telah dikaitkan dengan target SPM, namun perhitungan sasarannya baru pada posyandu, rumah sakit dan balai pengobatan bukan perindividu sasaran, karena anggaran telah dibatasi dan apabila dihitung persasaran individu anggaran akan cukup besar. (3) Realisasi dan kecukupan anggaran sebagian besar relatif terpenuhi, dan mencukupi, dan sebagian kecil ada juga kurang hal ini dapat disebabkan karena penghitungan anggaran hanya terfokus pada APBD Kota, sumber lain tidak dihitung dan kurang dimanfaatkan. Kekurangan dirasakan pada unit cost/harga satuan pada perjalanan dinas. (4) Sumber dana yang digunakan untuk melaksanakan kegiatan pada Dinas Kesehatan di Kota Jambi terdiri dari berbagai sumber yaitu APBD Kota, APBD Propinsi dan APBN. (5) Anggaran bukan satusatunya penyebab keberhasilan program ada faktor lain yang meliputi faktor internal yaitu kinerja petugas, motivasi petugas, kesesuaian target dengan keadaan di lapangan. Faktor eksternal yaitu lingkungan/masyarakat, kepercayaan, kesadaran dan kooperatif masyarakat terhadap program dan kemitraan yang dibangun.

Berdasarkan jumlah Anggaran Dinas Kesehatan Kota Jambi Tahun 2015 dan tahun 2016 memperlihatkan bahwa terdapat perbedaan jumlah anggaran yang disiapkan bagi peningkatan pelayanan kesehatan ibu, bayi, bayi 
baru lahir dan keluarga berencana, dimana anggaran pada tahun 2016 mengalami peningkatan dibandingkan dengan anggaran tahun 2015. Pada tahun 2015 anggaran yang disiapkan hanya sebesar Rp. 308.333.200, Sedangkan anggaran yang disiapkan bagi peningkatan pelayanan kesehatan ibu, bayi, bayi baru lahir dan keluarga berencana pada tahun 2016 sebesar Rp. 312.667.000 7,8 .

Adapun realisasi penggunaan anggaran pelayanan kesehatan ibu, bayi, bayi baru lahir dan keluarga berencana malah terjadi sebaliknya dimana realisasi anggaran pada tahun 2015 mencapai 268.131 .500 atau sekitar $86,9 \%$. sedangkan realisasi anggaran pada tahun 2016 menurun yaitu 260.229.400 atau sekitar 83,2\%. Hal ini terjadi karena terdapat faktor-faktor lain yang mempengaruhinya di antaranya lingkungan, perilaku dan data sasaran yang tidak sesuai dengan kenyataan.

Disamping itu terdapat juga cakupan yang termasuk dalam anggaran KIA seperti peningkatan dan pemberdayaan masyarakat bidang kesehatan dimana dana yang tersedia pada tahun 2016 sebesar 235.479.000, sedangkan realisasinya hanya sebesar 198.396.000 atau sekitar 82,3\%. Kemudian cakupan dalam pemberdayaan masyarakat untuk pencapaian keluarga sadar gizi dimana dana yang tersedia pada tahun 2016 sebesar 383.673.750, sedangkan realisasinya hanya sebesar 340.508.500 atau sekitar 88,7\%. Selain itu cakupan peningkatan pelayanan kesehatan anak dan remaja dan lansia yang juga termasuk dalam anggaran program KIA dimana dana yang tersedia pada tahun 2016 sebesar 312.667 .000 , sedangkan realisasinya hanya sebesar 260.229.400 atau sekitar 83,2\%.

\section{Analisis Pembiayaan Program KIA Terhadap Indikator Capaian Sesuai SPM}

Berdasarkan hasil wawancara diketahu bahwa, Dinas Kesehatan menentukan target dan tujuan sendiri dalam hal pembiayaan program KIA dalam merumuskan indikator capaian sesuai SPM. Hal ini dikarenakan target yang ditentukan dinas ada yang realistis dan tidak realistis. Idealnya Dinas Kesehatan Kota Jambi menentukan tujuan/ target sendiri agar tujuan yang ditentukan realistis artinya sesuai dengan realita yang terjadi di lapangan mengenai masalah Kesehatan Ibu dan Anak serta kemampuan Dinas untuk mencapainya.

Adapun kesesuaian target standar pelayanan minimal (SPM) dengan kenyataan ada yang realistis ada yang tidak, namun dari alasan yang dikemukakan cenderung tidak realistis. Ketidaksesuaian target dengan kenyataan di lapangan disebabkan angka target pada setiap indikator SPM dihitung dengan membandingkan capaian pelayanan dengan sasaran proyeksi, sedangkan sasaran proyeksi tidak selalu sama dengan kondisi dilapangan.

Dinas kesehatan Kota Jambi saat ini dalam menentukan sasaran sebagai penyebut untuk penghitungan pencapaian target program KIA didasarkan pada proyeksi yang dihitung dari jumlah penduduk dengan rumus sebagai berikut : (1) Jumlah perkiraan Sasaran ibu hamil 1,1 x CBR (angka kematian kasar) Kota $\mathrm{x}$ Jumlah penduduk di wilayah kerja (penyebut indikator cakupan kunjungan ibu hamil K-4), (2) Jumlah perkiraan sasaran persalinan $=1,05 \mathrm{x}$ CBR Kota $x$ Jumlah Penduduk (penyebut indikator Cakupan Linakes), (3) Jumlah sasaran ibu hamil resiko tinggi $=20 \%$ dari sasaran ibu hamil (penyebut indikator cakupan bumil resti yang dirujuk), dan (4) Jumlah seluruh bayi lahir hidup $=2,3 \% \mathrm{x}$ jumlah penduduk (penyebut indikator cakupan kunjungan nepnatus) Tidak semua wilayah/desa sesuai dengan proyeksi sebagian besar kenyataannya ada di bawah proyeksi, sehingga berpengaruh terhadap kesulitan dalam mencapai target cakupan program. 
Dinas Kesehatan Kota Jambi pada prakteknya mempunyai dua data yaitu data proyeksi dan data riil. Data riil diperoleh dari pendataan yang dilakukan oleh puskesmas, bidan desa dan kader sehingga dalam data riil itu tercantum by name by adress yang dapat dilacak. Dan data inilah yang digunakan acuan dalam pelacakan-pelacakan sasaran dan berfungsi sebagai pembanding ketika target proyeksi tersebut tidak tercapai sehingga puskesmas dapat mempertanggungjawabkan.

Berdasarkan data realisasi SPM bidang kesehatan Dinas Kesehatan Kota Jambi tahun 2016 menunjukkan bahwa hampir seluruh aktifitas Standar Pelayanan Minimal (SPM) tahun 2016 mengalami presentasi peningkatan yang signifikan antara target dan realisasi masing-masing cakupan pelayanan kecuali hanya dua cakupan pelayanan yang belum memenuhi target. Hal ini menandakan bahwa target yang ingin dicapai oleh dinas kesehatan Kota Jambi dianggap melibihi target yang di rencanakan. Namun demikian data diatas juga menunjukkan terdapat beberapa cakupan pelayanan yang belum memenuhi target yang ingin dicapai, seperti pada cakupan Neonatus dengan komplikasi yang ditangani, dimana target yang ingin dicapai $80 \%$ sedangkan realisasinya hanya $55 \%$. Kemudian cakupan peserta KB aktif dimana target yang ingin dicapai $70 \%$ sedangkan realisasinya hanya $62 \%$.

Proses perhitungan anggaran Dinas Kesehatan Kota Jambi telah melakukan 3 langkah perencanaan dari 5 tahapan/langkah yaitu Perencanaan, perkiraan dan penyesuaian dan 2 langkah berikutnya adalah implementasi dan evaluasi, yang akan dilaksanakan setelah penetapan anggaran. Pada penyusunan anggaran tersebut Dinas Kesehatan Kota Jambi juga melakukan advokasi dengan langkah menjual program-program pada stakeholder agar rencana anggaran dapat dibiayai dan dalam rangka mengoptimalkan alokasi anggaran karena kemampuan advokasi dinas kesehatan berpengaruh terhadap pembiayaan kesehatan.

Perhitungan anggaran pada dasarnya telah dikaitkan dengan target-target yang telah ditetapkan. Dalam pelaksanaannya tetap mempertimbangkan tenaga yang tersedia, biaya yang teralokasikan dan sarana prasarana yang ada. Metoda perencanaan yang didasarkan pada kebutuhan dan data dari bawah kecenderungannya pada perhitungan anggaran akan membengkak yang sulit untuk dibiayai dari dana bersumber pemerintah. Hal ini dapat diakibatkan ketidakjelasan pada masyarakat antara kebutuhan dan keinginan. Kebutuhan merupakan suatu masalah yang harus segera diselesaikan yang didukung dengan data, adapun keinginan lebih pada kemauan masyarakat.

Agar perencanaan dan penganggaran dapat berdasar kebutuhan dan data (evidance Based) dan dapat terealisasi sesuai dengan prioritas maka pendekatan bottom up dan top down perlu dilakukan artinya pendekatan bottom up adalah untuk melihat masalah yang berkembang di wilayah dinas kesehatan Kota Jambi untuk dibuat perencanaan dan penganggaran sedangkan top down dimaksudkan untuk menjaga agar standar pelayanan minimal yang harus ada di puskesmas dapat dimasukkan pada perncanaan dan penganggaran. Disamping untuk melihat usulan dari bawah merupakan masalah-masalah prioritas atau bukan.

Dinas Kesehatan Kota jambi lebih memilih model perhitungan yang diperkirakan akan terakomodir, hal ini sejalan dengan pendekatan penyusunan anggaran budget based targeting artinya besarnya anggaran telah ditetapkan terlebih dahulu, baru setelah itu target dan jenis kegiatan disesuaikan dengan besarnya anggaran yang tersedia walaupun 
pelaksanaannya tidak murni budget based targeting karena pada kenyataanya target yang harus dicapai juga telah ditetapkan terlebih dahulu pada Peraturan Walikota tentang Standar Pelayanan Minimal di Kota Jambi.

\section{Pada dana dekonsentarsi Dinas}

Kesehatan Kota Jambi dapat dikatakan tidak mempunyai kewenangan dalam perencanaan, hanya sebagai pelaksana kegiatan, yaitu kewenangan dan decision space yang dimiliki Dinas Kesehatan Kota Jambi, sehingga derajat otonomi Kota/Kab dalam dana dekonsentrasi program KIA juga sempit, karena dinas kabupaten/Kota mempunyai kewenangan yang sempit yang pada gilirannya menyebabkan unit yang berada dibawah naungannya otomatis juga mempunyai kewenangan dan decision space yang sempit dalam penyusunan perencanaan penganggaran.

Perkecualian terjadi pada penghitungan anggaran untuk keluarga miskin. Pelayanan kesehatan ibu dan anak keluarga miskin yang meliputi kunjungan ibu hamil, persalinan oleh tenaga kesehatan, ibu hamil resiko tinggi yang dirujuk, kunjungan neonatal, penanganan berat badan lahir rendah (BBLR) seluruhnya dihitung persasaran individu dengan unit cost tertentu Dinas Kesehatan Kota Jambi untuk pengaturan pembiayaan pelayanan KIA yaitu dengan menerbitkan surat yang mengatur penggunaan dana JKN untuk persalinan gakin.

Berdasarkan data yang hasil survei dan wawancara di lapangan dapat dikatakan bahwa secara umum perbandingan antara rencana dengan alokasi anggaran relatif terpenuhi dan cukup untuk melaksanakan kegiatan walaupun tidak sepenuhnya namun ada juga yang kurang. Hal ini dapat disebabkan karena penghitungan anggaran hanya terfokus pada APBD Kota. Ketidaksesuaian anggaran disebabkan juga kurang akuratnya estimasi pada saat menyusun perencanaan, seperti tidak diperhitungkannya penambahan fasilitas pada tahun pelaksanaan rencana berjalan, sehingga berakibat kekurangan anggaran pada tahap pelaksanaan.

\section{KESIMPULAN DAN SARAN}

Kesimpulan yang didapatkan dari hasil penelitian ini adalah Proses perencanaan dan penganggaran program KIA di Dinas Kesehatan Kota Jambi telah menggunakan pedoman P2KT bidang kesehatan dan menerapkan perencanaan dan anggaran yang berbasis kinerja. Sedangkan Analisa situasi, perumusan masalah dan penetapan tujuan program menggunakan metode yang dapat mengakomodir kebutuhan sebenarnya, dan alokasi anggaran program KIA termasuk salah satu program prioritas dibandingkan bidang lain. Anggaran yang disiapkan bagi peningkatan pelayanan kesehatan ibu, bayi, bayi baru lahir dan keluarga berencana pada tahun 2016 mengalami peningkatan dibandingkan dengan anggaran tahun 2015. Adapun realisasi penggunaan anggaran malah terjadi sebaliknya dimana realisasi anggaran pada tahun 2015 sekitar $86,9 \%$. sedangkan realisasi anggaran pada tahun 2016 sekitar 83,2\%. Kesesuaian pembiayaan program KIA terhadap indikator capaian sesuai SPM di Dinas Kesehatan Kota Jambi ada yang realistis, ada yang tidak dan cenderung tidak realistis. Ketidaksesuaian target dengan kenyataan di lapangan disebabkan angka target pada setiap indikator SPM dihitung dengan membandingkan capaian pelayanan dengan sasaran proyeksi, sedangkan sasaran proyeksi tidak selalu sama dengan kondisi dilapangan.

Adapun saran yang dapat diberikan yaitu mengoptimalisasi anggaran peningkatan kesehatan KIA perlu dilakukan realokasi dan perencanaan anggaran dari bawah (buttom up planing), terpadu antar kegiatan program dan anggaran dengan melakukan pemetaan terhadap kemampuan daerah demi menjamin pemerataan. Secara teoritis penelitian ini masih perlu 
ditindaklanjuti terutama tentang pembuktian adakah pengaruh anggaran terhadap cakupan program.

\section{DAFTAR PUSTAKA:}

1. Kementrian Kesehatan RI, Keputusan Menteri Kesehatan RI nomor: 43 Tahun 2016 tentang Standar Pelayanan Minimal Bidang Kesehatan. 2016

2. Peraturan Pemerintah Nomor 65 tahun 2005 tentang Pedoman Penyusunan dan Penerapan Standar Pelayanan Minimal.

3. Departemen Kesehatan RI, Keputusan Menteri Kesehatan RI nomor 128/Menkes/SK/II/2004 tentang Kebijakan Dasar Puskesmas. Depkes 2004.

4. Baswir Revrisond. Akutansi Pemerintah Indonesia, PT BPFE UGM Yogyakarta.

5. Gani Ascobat, Nadjib Madiati dan Chusnun Prastuti. Perencanaan dan Penganggaran Kesehatan Terpadu (P2KT). DHS.1, Depkes RI. 2004.

6. Dinas Kesehatan Provinsi Jambi, Profil Kesehatan Provinsi Jambi. Jambi: Dinas Kesehatan provinsi Jambi, 2014.

7. Dinas Kesehatan Kota Jambi. Anggaran Dana Dinas Kesehatan Kota Jambi Tahun 2015. Jambi: Dinas Kesehatan provinsi Jambi, 2015.

8. Dinas Kesehatan Kota Jambi. Anggaran Dana Dinas Kesehatan Kota Jambi Tahun 2016. Jambi: Dinas Kesehatan provinsi Jambi, 2016.

9. Azwar Azrul, Pengantar Administrasi Kesehatan,Edisi ketiga, Bina Putera Aksara, Jakarta 1996.

10. Biro Keuangan dan Perlengkapan Setkretariat Jenderal, Depkes RI, Template Pergitungan Biaya Kesehatan dalam rangka Kewenangan Wajib Standar Pelayanan Minimal (KW-SPM) Bidang Kesehatan di Kabupaten/Kota, 2005.

11. Biro Perencanaan Depkes RI, Fakultas Kesehatan Masyarakat Universitas Indonesia, Perencanaan dan Penganggaran Kesehatan
Terpadu : Prinsip Analisis Biaya dan Perhitungan Kebutuhan Biaya Program

12. Cholik Amin A, Perkembangan Perhitungan Biaya KW-SPM Bidang Kesehatan,materi padaPerhitungan Kebutuhan Biaya Pelaksanaan KW-SPM Regional Barat, yogyakarta, 2006.

13. Dinas Kesehatan Kota Jambi, Profil Dinas Kesehatan Kota Jambi. 2005

14. Dinas Kesehatan Propinsi Jambi, Perencanaan dan Penganggaran Kesehatan Terpadu Puskesmas, 2002

15. Gani Ascobat. Analisis Biaya dan Resiko Lingkungan. FKMUI

16. Harmana Tisa, B. Adisasmita Wiku, FaktorFaktor Yang Mempengaruhi Pembiayaan Kesehatan Daerah Bersumber Anggaran Pendapatan dan Belanja Daerah Tahun 2006, Jurnal Manajemen Pelayanan Kesehatan 2006, Volume 09

17. Mardiasmo, Akutansi Biaya Penentuan Harga Pokok Produksi, Andiofset, Yogyakarta, 1994

18. Marhaeni Dewi, Herawati Diah, Decision Space Dalam Program Kesehatan Ibu dan Anak Tahun 2006, Jurnal Manajemen Pelayanan Kesehatan 2006, Volume 09

19. Mulyadi, Akutansi Manajemen: Konsep Manfaat dan Rekayasa, STIE YKPN Yogyakarta 1993

20. Munandar M. Budgeting : Perencanaan Kerja Pengorganisasian Kerja Pengawasan Kerja,PT BPFE UGM Yogyakarta

21. Pedoman Pelaksanaan Jaminan pemeliharaan kesehatan masyarakat Miskin (ASKESKIN). Depkes. 2005.

22. Peraturan Menteri Dalam Negeri nomor 13 tahun 2006 tentang Pedoman Pengelolaan Keuangan Daerah

23. Thabrany Hasbullah, Perhitungan Biaya Kesehatan Dalam Implementasi KW SPM di Kabupaten/Kota dan Peran DHA (materi pelatihan), Pusat Kajian Ekonomi Kesehatan Universitas Indonesia

24. Tunggal Amin Widjaya. Dasar-dasar Budgeting, Rineka Cipta, Jakarta, 1995.

25. Undang-Undang nomor 32 tahun 2004 tentang Pemerintah Daerah 